\title{
PLATFORMY PEER-TO-PEER JAKO SDĚLOVÁNÍ VEŘEJNOSTI
}

\author{
JAN ZIBNER ${ }^{1}$
}

$\begin{array}{ll}\text { Soud: } & \text { Soudní dvůr Evropské unie } \\ \text { Věc: } & \text { C-610/15 } \\ \text { Datum: } & \text { 14. } 6.2017 \\ \text { Dostupnost: } & \text { curia.europa.eu }\end{array}$

\section{SHRNUTÍ SKUTKOVÉHO STAVU}

Spor, který vyústil v rozhodnutí Soudního dvora Evropské unie (dále jen „Soudní dvůr"), se týkal užívání online platformy pro sdílení souborů v podobě autorských děl a dalších výtvorů The Pirate Bay (dále jen "The Pirate Bay"). Nizozemské společnosti Ziggo $B V^{3}$ a XS4ALL Internet $B V^{A}$ (dále společně jen „Žalované společnosti“) primárně poskytovaly svým klientům přístup $\mathrm{k}$ internetu, kde podstatná řada $\mathrm{z}$ nich využívala právě platformu The Pirate Bay. Prostřednictvím té se dostávali k autorským dílům, u kterých oprávnění vykonavatelé autorských práv převážně neudělili svolení $\mathrm{k}$ užití provozovatelům této platformy ani uživatelům, a to aniž by o takové skutečnosti byli jednotliví uživatelé jakkoliv informováni. The Pirate Bay je

1 Mgr. Jan Zibner. Prezenční doktorský student na Ústavu práva a technologií (školitel JUDr. Matěj Myška, Ph.D.). Kontaktní e-mail: jan.zibner@mail.muni.cz.

2 Rozsudek Soudního dvora Evropské unie ze dne 14. června 2017. Stichting Brein proti Ziggo BV, XS4ALL Internet BV. Věc C-610/15. In: EUR-Lex [právní informační systém]. Úřad pro publikace Evropské unie [cit. 1. 10. 2017]. Dostupné z: http://eur-lex.europa.eu/legalcontent/CS/TXT/HTML/?uri = CELEX:62015CJ0610\&from = EN (dále jen „anotované rozhodnutí").

3 Společnost Ziggo BV registrovaná v Nizozemsku, se sídlem na adrese Atoomweg 100, Utrecht, 3542 AB, Nizozemsko.

4 Společnost XS4ALL Internet BV registrovaná v Nizozemsku, se sídlem na adrese Eekholt 42, Diemen, 1112 XH, Nizozemsko. 
navíc specifická ve způsobu zpřístupňování obsahu, neb tento je prezentován ve formě souborů BitTorrent ${ }^{5}$. Na druhé straně pak vystupovala nizozemská nadace Stichting Brein ${ }^{6}$ zastupující zájmy nositelů autorských práv, která se domáhala zamezení takového zpřístupňování obsahu.

\section{2. ŘÍZENÍ PŘED NÁRODNÍM SOUDEM}

Nadace Stichting Brein se před nizozemskou justicí domáhala toho, aby Žalované společnosti byly nuceny blokovat př́slušná doménová jména a IP adresy platformy The Pirate Bay. To vše s cílem chránit zájmy vykonavatelů autorských práv, které tím nadaci pověřili, a zamezit protiprávnímu užívání děl skrze torrenty ve spolupráci $\mathrm{s}$ The Pirate Bay. V prvním stupni soud návrhům Stichting Brein vyhověl, ${ }^{7}$ nicméně odvolací soud rozhodnutí zrušil a návrhy zamítnul s odkazem na porušování autorských práv jednotlivými uživateli, nikoliv Žalovanými společnostmi, a na nepřiměřenost blokace při poměřování $s$ účelem ochrany autorských práv. ${ }^{8}$ Věc se pak dostala až před Nejvyšší soud (Hoge Raad der Nederlanden), který sice ve svém rozhodnutí potvrdil, že skrze platformu The Pirate Bay dochází ke zpř́stupňování chráněných děl veřejnosti bez jakýchkoliv souhlasů oprávněných vykonavatelů autorských práv a že tato díla jsou užívána klienty Žalovaných společností. ${ }^{9}$ Nicméně druhým dechem dodává, že v kontextu judikatury Soudního dvora na téma sdělování veřejnosti

\footnotetext{
BitTorrent je protokol pro sdílení souborů mezi uživateli (peers) skrze rozčlenění jednotlivých souborů (torrentů) a ukládání těchto částí mimo hlavní server. Děje se tak prostřednictvím specializovaných klientů umožňujících takové rozčlenění a vytváření torrentů ve spolupráci s databází jako The Pirate Bay coby základním pojícím prvkem mezi těmi, kdo jednotlivé torrenty zpřístupňují (seeders) a kdo je stahují (leechers). Speciální formou stahování torrentů je pak stahování prostřednictvím provázaných odkazů (magnet links), které na torrenty odkazují přes jedinečné digitální stopy. Stahování soborů torrent samo o sobě též představuje sdělování veřejnosti.

6 Společnost Stichting Brein registrovaná v Nizozemsku, se sídlem na adrese Postbus 133, 2130 AC Hoofddorp, Nizozemsko.

7 Srov. rozhodnutí soudu prvního stupně ze dne 11. 1. 2012, sp. zn. 374634 / HA ZA 103184. In: Rechtspraak [online]. Netherlands Council for the Judiciary [cit. 25. 10. 2017]. Dostupné z: http://deeplink.rechtspraak.nl/uitspraak?id =ECLI:NL:RBSGR:2012:BV0549

8 Srov. rozhodnutí odvolacího soudu ze dne 28. 1. 2014, sp. zn. 200.105.418-01. In: Rechtspraak [online]. Netherlands Council for the Judiciary [cit. 25. 10. 2017]. Dostupné z: http://deeplink.rechtspraak.nl/uitspraak?id = ECLI:NL:GHDHA:2014:88
} 
s odkazem na čl. 3 odst. $1^{10}$ Směrnice InfoSoc ${ }^{11}$ není možné pro specifika tohoto případu jednoznačně dospět $k$ závěru. Specifika přitom Nejvyšší soud spatřuje ve vytváření a údržbě systému pro interakci uživatelů za účelem sdílení fragmenti̊ chráněných děl přítomných v externích počítačích, jakož i v provozu webové platformy pro zpřístupňování torrentů a jejich indexaci související s ukládáním takových souborů do vlastních počítačů. ${ }^{12}$

\section{PŘEDBĚŽNÁ OTÁZKA}

Na základě těchto pochyb se Nejvyšší soud rozhodl řízení přerušit a Soudnímu dvoru předložit předběžnou otázku, která by bud' posunula chápání institutu sdělování veřejnosti o krok dál mimo oblast samotných uživatelů, nebo naopak uzavřela tento institut $\mathrm{v}$ již zajetých standardech a nastolila tím limity interpretace. Předběžná otázka, která byla doručena Soudnímu dvoru dne 18. listopadu 2015, zněla:

„1) Jedná se o sdělování veřejnosti ve smyslu čl. 3 odst. 1 směrnice 2001/29 provozovatelem internetové stránky, jestliže tato internetová stránka neobsahuje žádná chráněná díla, avšak existuje systém $[. . .]^{13}$, prostřednictvím něhož se indexují a kategorizují metainformace o chráněných dỉlech, jež se nacházejí v zařżeních uživatelů, aby uživatelé následně na základě těchto informací dokázali nacházet, nahrávat a stahovat chráněná díla?

2) V př́padě záporné odpovědi na první otázku: Lze na základě čl. 8 odst. 3 směrnice 2001/29 a článku 11 směrnice 2004/48 vydat soudní př́kaz vůči

9 Srov. bod 15 anotovaného rozhodnutí; rozhodnutí Nejvyššího soudu Nizozemska ze dne 13. 11. 2015, sp. zn. 14/02399. In: Rechtspraak [online]. Netherlands Council for the Judiciary [cit. 25. 10. 2017]. Dostupné z: http://deeplink.rechtspraak.nl/uitspraak?id=ECLI:NL: HR:2015:3307

10 „Členské státy poskytnou autorům výlučné právo udělit svolení nebo zakázat jakékoliv sdělení jejich děl veřejnosti po drátě nebo bezdrátově včetně zpř́stupnění jejich děl veřejnosti takovým způsobem, že každý jednotlivec ze strany veřejnosti má $k$ těmto dílưm př́stup z místa a $v$ době, které si zvoli. “ Čl. 3 odst. 1 směrnice 2001/29/ES.

11 Směrnice Evropského parlamentu a Rady 2001/29/ES ze dne 22. května 2001 o harmonizaci určitých aspektů autorského práva a práv $\mathrm{s}$ ním souvisejících $\mathrm{v}$ informační společnosti. In: EUR-lex [právní informační systém]. Úřad pro publikace Evropské unie [vid. 8-10-2017]. Dostupné z: http://eur-lex.europa.eu/LexUriServ/LexUriServ.do?uri=CELEX:32001L0029:CS:HTML (dále jen „směrnice InfoSoc“).

12 Srov. bod 16 anotovaného rozhodnutí; rozhodnutí Nejvyššího soudu Nizozemska ze dne 13. 11. 2015, sp. zn. 14/02399, op. cit.

13 Původní znění otázky obsahuje odkaz na články žádosti o rozhodnutí o předběžné otázce. 
zprostředkovateli či prostředníku ve smyslu těchto ustanovení, kteři způsobem uvedeným v první otázce usnadňují třetím osobám protiprávní jednání?“

\section{4. ÚVAHY SOUDU}

Soudní dvưr před svými úvahami vedoucími k závěru začal vymezením podstaty předběžné otázky. ${ }^{14} \mathrm{~V}$ tomto kontextu pak sděluje, že:

„Podstatou první otázky předkládajícího soudu je, zda musí být pojem „sdělování veřejnosti“ ve smyslu čl. 3 odst. 1 směrnice 2001/29 vykládán v tom smyslu, že za takových okolností jako ve věci v pưvodním ř̀̇zení zahrnuje zpř́stupnění a správu platformy pro sdílení na internetu, která prostřednictvím indexace metadat týkajících se chráněných děl a poskytování vyhledávače umožňuje uživatelưm této platformy tato díla nacházet a sdílet je v rámci sítě „peer-topeer". “15

Ruku v ruce s dřívějším rozhodnutím ve věci $C-527 / 15^{16}$ a s poukazem na čl. 3 směrnice InfoSoc a v něm zakotvenou preventivní povinnost členských států zajistit autorům právo udělit svolení nebo zakázat sdělování svého díla veřejnosti, čemuž odpovídá i preventivní právo autorů zasáhnout tam, kde by uživatelé zamýšleli jejich dílo veřejnosti sdělovat, Soudní dvůr zdůraznil svou předchozí judikaturu na téma tohoto institutu. Uvedl, že pro absenci upřesnění pojmu sdělování veřejnosti je třeba smysl a dosah interpretovat souladně s cíli směrnice InfoSoc, tj. zavedení vysoké úrovně ochrany autorů spočívající mimo jiné v možnosti obdržet odpovídající odměnu zejména za sdělování děl veřejnosti, ${ }^{17}$ a plně v duchu teleologického výkladu, tedy široce a ryze individuálně. ${ }^{18}$

\footnotetext{
${ }^{14}$ Soudní dvưr se ve své rozhodovací praxi často uchyluje ke změnám znění podané předběžné otázky. Děje se tak pomocí vymezování její podstaty. Ovšem v řadě případů se znění otázky změní natolik, že Soudní dvưr neodpovídá přesně na to, na co byl dotazován, což může vést $\mathrm{k}$ nesouladu mezi jeho závěry a závěry potřebnými, jakož i k ohýbání právní jistoty (viz dále).

15 Bod 18 anotovaného rozhodnutí.

16 Rozsudek Soudního dvora ze dne 26. dubna 2017. Stichting Brein proti Jacku Frederiku Wullemsovi (Filmspeler). Věc C-527/15. In: EUR-Lex [právní informační systém]. Úřad pro publikace Evropské unie [cit. 1. 10. 2017]. Dostupné z: http://eur-lex.europa.eu/LexUriServ/LexUriServ.do?uri = CELEX:62015CJ0527:CS:HTML

17 Srov. bod 9 a 10 odůvodnění směrnice InfoSoc.

${ }^{18}$ Srov. body 20-23 anotovaného rozhodnutí, jakož i bod 23 odůvodnění směrnice InfoSoc.
} 
V další části se Soudní dvůr věnoval samotným základům sdělování veřejnosti. Tento institut má totiž dvě části, sdělování a veřejnost coby kumulativní prvky, přičemž je vždy třeba přihlížet $\mathrm{k}$ nejrůznějším doplňujícím a provázaným kritériím. Mezi nimi soud vyzdvihuje jako fundament samotného uživatele zpřístupňujícího - při plném vědomí svého jednání a důsledků díla dalším uživatelům ${ }^{19}$ - bipartici specifické technologie odlišné od té, které byly doposud používány, na jedné straně a nové veřejnosti, tedy veřejnosti, kterou nositelé autorského práva nebrali v potaz při prvním sdělování veřejnosti, na straně druhé, ${ }^{20}$ nebo výdělečnou povahu samotného sdělování. ${ }^{21}$

Soudní dvůr se ve své analýze dále pozastavil u přenosu díla pro veřejnost nepřítomnou v místě, ze kterého sdělování vychází, jakož i u zpřístupnění takovým způsobem, aby byl př́stup umožněn $\mathrm{v}$ místě a okamžiku, že si jednotliví uživatelé zvolí, bez ohledu na skutečné využití možnosti konzumace díla (potenciální percepce), a to i v kontextu internetových stránek a odkazů. ${ }^{22}$

Veškeré tyto úvahy přitom představovaly závěry dosavadní rozhodovací praxe Soudního dvora v otázce sdělování veřejnosti, které komplexně vedou $\mathrm{k}$ tomu, že $\mathrm{v}$ podstatě jakékoliv jednání uživatele plně známého takového jednání a následků spočívající ve zpřístupnění chráněných děl ostatním může naplňovat pojmové znaky sdělování. $V$ tomto případě Soudní dvůr svou předchozí judikaturu reflektoval tam, kde tvrdí, že v př́padě The Pirate Bay jsou díla zpřístupňována tak, aby k nim ostatní měli přístup dle svých preferencí.

Nejpodstatnější částí je pak úvaha nad subjektem, který díla vlastně zpřístupňuje, neb v př́ípadě torrentů jsou díla zpřístupňována vědomě či nevědomě uživateli, nikoliv správcem platformy The Pirate Bay. Nicméně

19 Srov. bod 26 anotovaného rozhodnutí a bod 50 stanoviska generálního advokáta Macieje Szpunara předneseného dne 8. února 2017. Stichting Brein proti Ziggo BV, XS4ALL Internet BV. Věc C-610/15. In: EUR-Lex [právní informační systém]. Úřad pro publikace Evropské unie [cit. 1. 10. 2017]. Dostupné z: http://eur-lex.europa.eu/legalcontent/CS/TXT/HTML/?uri = CELEX:62015CC0610\&from = EN (dále jen „stanovisko generálního advokáta").

${ }^{20}$ Srov. bod 28 anotovaného rozhodnutí a bod 47 stanoviska generálního advokáta.

${ }^{21}$ Srov. bod 29 anotovaného rozhodnutí.

22 Srov. body 30-33 anotovaného rozhodnutí. 
i skrze provoz a správu této platformy provozovatelé jednají s plným vědomím svého jednání a s cílem poskytnout přístup ke chráněným dílům a tato sdílet. Bez tohoto jednání by totiž $\mathrm{k}$ samotnému zpř́stupnění a sdílení děl nedocházelo vůbec, či ne $\mathrm{v}$ takovém rozsahu jako $\mathrm{s}$ využitím platformy. ${ }^{23}$ Ergo tito provozovatelé hrají nepominutelnou roli při zpřístupňování př̀edmětných děl. Navíc nelze mít dle Soudního dvora za to, že by se $\mathrm{v}$ tomto případě jednalo pouze o poskytování fyzického zařízení pro umožnění nebo uskutečnění sdělování veřejnosti ve smyslu směrnice InfoSoc ${ }^{24}$, neb samotná podstata platformy The Pirate Bay tkví v indexaci torrentů a usnadnění explorace internetu a stahování chráněných děl, což podtrhuje i multifunkční rejstř́ík torrentové materie dostupný na této platformě či aktivní dohled a filtrace obsahu správci platformy. ${ }^{25}$

Poslední část rozhodnutí je věnována otázce samotné veřejnosti coby minimálnímu prahu adresátů. ${ }^{26}$ Zde je potřeba dle Soudního dvora primárně zkoumat vedle dalšího kumulativní účinky zpřístupnění potenciálním adresátům, kteréžto hledisko $\mathrm{v}$ př́padě The Pirate Bay představovalo desítky milionů uživatelů, jakož i kritérium nové veřejnosti, které vlivem přímého podněcování provozovatelů ke sdílení souborů a explicitního zpřístupňování děl chráněných autorským právem za účelem dosahování zisku je též naplněno. ${ }^{27}$

\section{ROZHODNUTÍ SOUDU}

Soudní dvůr v návaznosti na svého úvahy uvedl, že

„Pojem „sdělování veřejnosti“ ve smyslu čl. 3 odst. 1 směrnice Evropského parlamentu a Rady 2001/29/ES ze dne 22. května 2001 o harmonizaci určitých aspektů autorského práva a práv s ním souvisejících vinformační společnosti musí být vykládán $v$ tom smyslu, že za takových okolností jako ve věci v pưvodním ř́zení zahrnuje zpř́stupnění a správu platformy pro sdílení na internetu, která prostřednictvím indexace metadat týkajících se chráněných dèl

\footnotetext{
${ }^{23}$ Srov. body 35-37 anotovaného rozhodnutí; k tomu srov. body 45 a 50 stanoviska generálního advokáta.

${ }^{24}$ Srov. bod 27 odůvodnění směrnice InfoSoc.

${ }^{25}$ Srov. bod 38 anotovaného rozhodnutí a body 19-27 stanoviska generálního advokáta.

${ }^{26}$ Srov. bod 41 anotovaného rozhodnutí.

${ }^{27}$ Srov. body $42-47$ anotovaného rozhodnutí.
} 
a poskytování vyhledávače umožňuje uživatelům této platformy tato díla nacházet a sdílet je v rámci sítě „peer-to-peer“.“

Na první část předběžné otázky tedy Soudní dvůr odpovídá v tom smyslu, že byt samotné provozování a správa platformy The Pirate Bay (resp. internetová stránka, která neobsahuje žádná chráněná díla, avšak existuje systém, prostřednictvím něhož se indexují a kategorizují metainformace o chráněných dílech, jež se nacházejí v zařízeních uživatelů, aby uživatelé následně na základě těchto informací dokázali nacházet, nahrávat a stahovat chráněná díla - abychom odpověděli na skutečnou předběžnou otázku, ne její upravené znění) je sdělováním veřejnosti, ač samotný akt zpřístupňování díla spočívá na straně jednotlivých uživatelů.

Vzhledem k tomu, že Soudní dvưr první předběžnou otázku zodpověděl kladně, bylo bezpředmětné zabývati se otázkou druhou směřující na alternativní postup $\mathrm{v}$ podobě soudního prríkazu $\mathrm{k}$ omezení nebo zákazu činnosti.

\section{REFLEXE ROZHODNUTÍ}

Soudní dvůr ve svých úvahách mohutně odkazoval na své předchozí rozhodnutí v otázce sdělování veřejnosti, shora citovaného rozhodnutí ve věci C-527/15 (známé pod populárním názvem Filmspeler) a v něm citovanou judikaturu. Je tak vidět, že Soudní dvůr se pomalu odtrhuje od základních rozhodnutí v otázce sdělování veřejnosti, ve kterých dospívá k dílčím závěrům $\mathrm{u}$ jednotlivých aspektů tohoto institutu (jako jsou rozhodnutí populárně známá jako $S G A E^{28}$, BestWater ${ }^{29}$ apod.), a argumentaci směřuje již jen tam, kde jsou veškerá jeho rozhodnutí sumarizovaně citována a pro čtenáře dostupná na jednom místě. Tím na jedné straně do jisté míry zpřehledňuje svůj argumentační aparát a centralizuje zdroje svých úvah, nicmé-

${ }^{28}$ Rozsudek Soudního dvora ze dne 7. prosince 2006. Sociedad General de Autores y Editores de España (SGAE) proti Rafael Hoteles SA. Věc C-306/05. In: EUR-Lex [právní informační systém]. Úřad pro publikace Evropské unie [cit. 1. 10. 2017]. Dostupné z: http://eurlex.europa.eu/legal-content/CS/TXT/HTML/?uri = CELEX:62005CJ0306\&from = EN

29 Rozsudek Soudního dvora ze dne 13. února 2014. Nils Svensson, Sten Sjögren, Madelaine Sahlman, Pia Gadd proti Retriever Sverige ABA. Věc C-466/12. In: EUR-Lex [právní informační systém]. Úřad pro publikace Evropské unie [cit. 1. 10. 2017]. Dostupné z: http://eur-lex.europa.eu/LexUriServ/LexUriServ.do?uri = CELEX:62012CJ0466:CS:HTML 
ně podložení svých závěrů a obeznámení s nimi na straně druhé přenáší ze své sféry na osobu čtenáře.

Soudní dvůr v tomto rozhodnutí též opět trochu poupravil znění předběžné otázky, a to svým výkladem podstaty otázky, který předchází, jak shora uvedeno, dalším úvahám Soudního dvora. Tento postup je však veřejností kritizován. ${ }^{30} \mathrm{~V}$ pozměněném zadání totiž můžeme nalézt jemné rozdíly.

Zatímco původně položená předběžná otázka cílí na samotného provozovatele sítě, resp. internetové stránky, a předkládající soud se táže, zda tato osoba sděluje takto díla veřejnosti, upravené znění pracuje s platformou (a jejím zpřístupněním a správou) jako prostředkem sdělování veřejnosti odtrženě od osoby provozovatele. Osoba provozovatele ve výkladu Soudního dvora již není zahrnuta. Avšak osoba provozovatele internetové stránky se může lišit od toho, kdo platformu zpřístupní a bude spravovat, či tyto činnosti mohou být vykládány jinak. Provozovatel (operator) je totiž již ze své podstaty subjekt pověřený administrativou webové stránky v širokém slova smyslu a který má navíc oprávnění $\mathrm{k}$ její celkové rekonfiguraci, znepřístupnění, jakož i blokaci uživatelů. Na rozdíl od toho zpřístupnění a správa (making available and management) pak jsou jen dílčí operace figurující v rámci širokého oprávnění provozovatele, které se soustředí na prvotní komunikování webové stránky směrem $\mathrm{k}$ uživatelům a na aktivní dohled nad obsahem takové stránky. ${ }^{31}$ Lze je tedy vnímat jako užší výseč jeho činností. Nehledě na to, že těmito činnostmi mohou být pověřeny třetí osoby a otázka odpovědnosti pak nabude zcela jiný rozměr. Na tomto místě Soudní dvưr nad rámec přenosu materie z osoby na platformu tedy zúžil rozsah tázané otázky. Otázkou tedy zůstává, do jaké míry je roz-

30 Srov. VOSS, Katharina. But That's Not What I Asked! The Reformulation of Questions Asked in Preliminary Rulings. Europarättslig tidskrift, 2015, roč. 18, č. 4, s. 939-956. ISSN 1403-8722; VOUSDEN, Stephen. Autonomy, comparison websites, and Ryanair. Intellectual Property Quarterly. 2015, roč. 19, č. 4, s. 386-406. ISSN 1364-906X.

31 K funkcím provozovatele webové stránky srov. Web Site Operator Capabilities and Limitations. Microsoft Support [online]. Microsoft. Publikováno 30. 6. 2008 [cit. 29. 10. 2017]. Dostupné z: https://support.microsoft.com/en-us/help/298969/web-site-operatorcapabilities-and-limitations; $\mathrm{k}$ přehledu funkcí a odpovědnosti pak TAO, Qian. Intermediary Liability of Website Operators in Privacy Cases in China. Masaryk Journal of Law and Technology. 2011, roč. 5, č. 1, s. 105-118. ISSN 1802-5943. 
hodnutí možno na osobu provozovatele vztáhnout. Podle všeho dochází ke sdělování veřejnosti jen tam, kde skrze provozovatele bude webová platforma zpř́stupněna a aktivně spravována, jak říká anotované rozhodnutí. Nicméně ne obecně $\mathrm{v}$ př́ípadě provozovatele, jak se tázal nizozemský nejvyšší soud.

Zde dlužno podotknout, že generální advokát ve svém stanovisku s osobou provozovatele pracoval a od samotné platformy ho odlišoval, neb o této platformě se $\mathrm{v}$ jeho stanovisku hovoří jako o službě zprostředkovate$1^{\circ 32}$, čímž se má na mysli služba Žalovaných společností. I samotný závěr generálního advokáta k první otázce pak cílil př́ímo na provozovatele, ačkoliv nad rámec tázané otázky generální advokát dodal podmínky, že se jedná o sdělování veřejnosti provozovatelem, pokud tento provozovatel

„věděl o tom, že dílo bylo na síti zpř́stupněno bez svolení nositelů autorských práv, a nejednal s cílem př́stup $k$ tomuto dílu znemožnit. “33

Stejně tak lze rozdíl spatřovat $\mathrm{v}$ explicitním posunutí znění otázky do rovin čistých „peer-2-peer sítí“ (tedy vztah klient-klient a bez využití centrálního serveru), o kterých opět $\mathrm{v}$ původním znění předkládací soud nehovoří. Předkládací soud se tázal na internetové stránky, na nichž existuje systém pro indexaci dat, aby uživatelé na základě nich mohli nacházet, nahrávat a stahovat chráněná díla z počítačů dalších uživatelů. Ve středu původního řízení sice byla platforma The Pirate Bay jako základní a nejznámější prostředek čisté peer-2-peer sítě, ale původní znění otázky bylo trochu širší. Soudní dvůr měl možnost zaujmout stanovisko např́klad i pro situace nepřímého, tedy zprostředkovaného stahování skrze centrální server, kteréžto možnosti se s neustále narůstající blokací klasických peer2-peer sítí a platforem mohou objevit. I zde tedy Soudní dvůr své úvahy již na začátku zúžil a cíleně zamířil jen na čisté peer-2-peer sítě a platformu The Pirate Bay.

Samotné zpřístupnění a správa platformy The Pirate Bay jako sdělování veřejnosti je pak zlomovým momentem, který s narůstající mírou nelegálního stahování a obecně šíření zákonem chráněného obsahu má své opod-

${ }^{32}$ Srov. např. bod 60 stanoviska generálního advokáta.

${ }^{33}$ Bod 85 (závěr) stanoviska generálního advokáta; $\mathrm{k}$ samotnému znemožnění př́istup pak srov. body 51 a 53 stanoviska generálního advokáta. 
statnění. Posouvá totiž tento institut o krok před uživatele samotného, který prostřednictvím torrentů dílo - v drtivé většině případů nelegálně - sděluje veřejnosti, ${ }^{34}$ a míři tak co nejblíž porušování autorských práv. V minulosti sílil v kontextu nástupu technických komunikačních prostředků a nových způsobů komunikace všeobecný tlak vykonavatelů majetkových práv autorských na blokaci této platformy, a v některých národních právních řádech se to více či méně dařilo. ${ }^{35}$ Avšak na úrovni mezinárodni chybělo explicitní řešení ve smyslu deklarace nelegálního jednání dle některého $\mathrm{z}$ ustanovení mezinárodních právních předpisů. Doposud byly podobné platformy nahlíženy spíše jako poskytnutí fyzického zařízení pro umožnění nebo uskutečnění sdělování veřejnosti ve smyslu směrnice InfoSoc. ${ }^{36}$ A ty samy o sobě sdělování veřejnosti nepřestavují. Až nyní se Soudní dvůr vydal opačnou cestou a explicitně stanovil zpřístupnění a správu platforem typu The Pirate Bay jako akt sdělování veřejnosti. Tím jednak rozšířil dopad institutu sdělování veřejnosti na takovou platformu a zprostředkovatele zpřístupněného obsahu, jednak poukázal na druhotnou roli uživateli̊ na internetu a sílící vliv obdobných platforem, které - jak sám Soudní dvůr poukazuje - rapidně zlehčují zpřístupňování nelegálního obsahu na úkor uživatelů, kteří o nelegálnosti svého jednání vlivem neupozornění na stránkách dané platformy mnohdy nemusejí mít ponětí.

Anotované rozhodnutí v tomto smyslu jednoznačně podporuje ochranu autorského práva na internetu a vcelku i pružně reaguje na neustálý vývoj v této oblasti. Do budoucna lze ze strany Soudního dvora očekávat další široký výklad tohoto institutu a subsumpci dalších prostředků a způsobů komunikace pod sdělování veřejnosti.

\footnotetext{
34 Stahování souborů torrent je samo o sobě sdělováním veřejnosti, nebot dochází ke zpřístupňování díla ve smyslu čl. 3 směrnice InfoSoc právě jeho sdílením s ostatními uživateli, at už v minimálně omezitelné, či maximální neomezené hodnotě.

35 Srov. ucelený přehled zemí a způsobů blokace shrnutý v příspěvku Countries blocking access to The Pirate Bay. Wikipedia [online]. Wikipedia. Publikováno 23. 9. 2017 [cit. 29. 10. 2017]. Dostupné z: https://en.wikipedia.org/wiki/Countries_blocking_access_to_The_Pirate_Bay

36 Srov. čl. 27 odůvodnění směrnice InfoSoc, jakož i bohatá judikatura SDEU v této otázce.
} 
Toto dílo lze užít v souladu s licenčními podmínkami Creative Commons BY-SA 4.0 International (http://creativecommons.org/licenses/by-sa/4.0/legalcode). 